\title{
A Calix[4]arene-Functionalized Perylene Imide and Its Luminescence Properties
}

\author{
Giulia Murbach-Oliveira ${ }^{a, b}$ and Izilda A. Bagatin ${ }^{\circledR} * a$ \\ ${ }^{a}$ Laboratório de Química de Calixarenos, Espectroscopia Molecular e Catálise, \\ Instituto de Ciências Ambientais, Químicas e Farmacêuticas, Universidade Federal de São Paulo, \\ Campus Diadema, 09972-270 Diadema-SP, Brazil \\ ${ }^{b}$ Department of Chemistry, Purdue University, IN 47907 West Lafayette, USA
}

\begin{abstract}
In this study, new perylene-derived molecules were synthesized as perylene3,4,9,10-tetracarboxylic acid monoanhydride monopotassium carboxylate 1; $N$-(3-propanol) perylene-3,4,9,10-tetracarboxylic-3,4-(monoimide)anhydride-9,10-acid potassium carboxylate 2; 5,11,17,23-tetra(tert-butyl)-25,27-bis(3'-bromopropoxy)-26,28-(dihydroxy)calix[4]arene 3; 5,11,17,23-tetra(tert)butyl)-25-(3'-bromopropoxy)-27-( $N$-[3'(3'-propoxy)propyl]perylene(3',4',9', 10'-tetracarboxylic-3',4' -(monoimide)anhydride-9', 10'-acid potassium carboxylate)26,28-(dihydroxy)calix[4]arene 4. They were characterized by nuclear magnetic resonance $\left({ }^{1} \mathrm{H} \mathrm{NMR},{ }^{1} \mathrm{H}-{ }^{1} \mathrm{H}\right.$ correlation spectroscopy $(\mathrm{COSY}),{ }^{1} \mathrm{H}-{ }^{13} \mathrm{C}$ heteronuclear single quantum coherence spectroscopy (HSQC), ${ }^{1} \mathrm{H}_{-}{ }^{13} \mathrm{C}$ heteronuclear multiple bond correlation (HMBC)), Fourier transform infrared (FTIR), UV-Vis, and luminescence spectroscopies, besides elemental analysis. Cyclic voltammetry and spectroelectrochemical behavior techniques showed a well-defined one-electron reversible process. The compounds have high emission quantum yield and are very stable electronreceptors. Ligand 4 has a broad emission shifted to $540 \mathrm{~nm}$ based on its precursor 2, shown at $531 \mathrm{~nm}$. However, ligand $4(\phi=0.31)$ depicted a quantum yield lower than compound $\mathbf{2}(\phi=0.57)$, indicating that association with calixarene slightly decreases quantum yield. Nevertheless, it improves solubility significantly in organic solvents, which renders it useful for applications in the development of organic light-emitting diode (OLEDs) or biological markers.
\end{abstract}

Keywords: calixarene, perylene, luminescence, electrochemical behavior

\section{Introduction}

Calixarenes are macrocycles resulting from the condensation of $p$-substituted phenols and formaldehyde groups. ${ }^{1,2} \mathrm{~A}$ wide range of synthesis strategies arise from the possibilities of functionalization and combination of phenolic groups, as well as of association between different calixarenes. As both upper and lower calixarene rims can be functionalized with various groups, the introduction of one group to the aromatic ring could alter its reactivity, and planning is required to respect this condition. ${ }^{3}$ Accordingly, due to these numerous possibilities, some properties are commonly observed, such as high melting points; low solubility in water, good solubility in organic solvents; excellent flexibility and different cavity sizes; possibility of forming coordination compounds with metals and neutral molecules; well-defined oligomers and thermal stability. ${ }^{1}$

*e-mail: ibagatin@unifesp.br, ibagatin@gmail.com

Dedicated to Prof Henrique Eisi Toma on the occasion of his $70^{\text {th }}$ birthday.
As a result of their structure associated with different functionalizations and their physicochemical properties, calixarenes are considered for an assortment of industrial applications, such as stabilizers for organic polymers and neutral organic molecules separation, ${ }^{4,5}$ besides the already observed selective complexes formation with certain metals, as hazardous metal sequestrations such as uranium and cesium, phase transfer agents, accelerators for instant adhesives, Langmuir-Blodgett films membranes, and catalysts. ${ }^{4-6}$ In addition to these, new applications have been outlined for calixarenes, such as fluorescent biological markers and in light-emitting devices, ${ }^{7-10}$ as the OLEDs, organic light-emitting diodes.

In order to make calixarenes appropriate for the latter two applications, it is necessary to attach them to luminescent molecules. Examples of such molecules are perylene derivatives such as perylene carboxydiimides, which have electron-receptor activity and may be applied to electronic transport systems. ${ }^{11-16}$ Additionally, they have high quantum yield, significant thermal and photochemical 
stability, and are particularly stable electron receptors. However, they are very insoluble due to the formation of dimers and $\pi-\pi$ stacking aggregates. ${ }^{11-16}$

The luminescent properties of the perylene derivatives may be modified according to the type of substituent attached to them. For example, perylene derivatives attached to donor electron groups have increased energy from their HOMO (highest occupied molecular orbital) and LUMO (lowest unoccupied molecular orbital) orbitals, making them p-type conductors. Conversely, when perylenes are bound to receptor electron groups, the energies of their HOMO and LUMO orbitals decrease, and they are considered n-type conductors. As far as n-type organic molecules are concerned, they are especially interesting due to the low number of such-type molecules as compared to p-type. Perylenes have a high potential to become n-type conductors due to their electron relocation by conjugation and their high electronic affinity. ${ }^{17,18}$

Organic biological markers are interesting because they are comparatively smaller molecules than natural fluorophores, allowing their use in macromolecule bioconjugations, such as antibodies. To be used for this purpose, organic chromophores must have solubility and high photostability. ${ }^{19}$

One method to evaluate the efficiency of biological markers and their usefulness in marking specific targets is the "fluorochrome brightness index". The choice of the appropriate fluorophore for each application and the apparatus to be used, as an instance, the flow cytometry technique, can be supported by that index. The brightness index comprises a range from 1 (faint brightness) to 5 (higher intensity). ${ }^{20,21}$

The goal of this work is the synthesis, characterization, and luminescence study of a novel perylene-imide calixarene-based ligand, improving its solubility to a promising candidate for applications in light-emitting devices, fluorescent biological markers, and fluorescent sensors.

\section{Experimental}

\section{Reagents and apparatus}

The syntheses were carried out on inert atmosphere employing a Schlenk flask. All solvents were PA-ACS (98-99\%) grade, purchased from Sigma-Aldrich (St. Louis, MO, USA) and were utilized without treatment except for the case of the dimethylformamide (DMF, 99\%) from Synth (Diadema, Brazil), which was purified and distilled. The reagents were PA-ACS (98-99\%) grade and purchased from Sigma-Aldrich (St. Louis, MO, USA) or Merck (Darmstadt, Germany) and utilized without additional purification. Syntheses were monitored by TLC (thin-layer chromatography) on silica gel 60 (0.25 mm) from Merck (Darmstadt, Germany), and the purification of compounds was conducted on $\mathrm{SiO}_{2} 60$ from Merck (Darmstadt, Germany).

${ }^{1} \mathrm{H}$ nuclear magnetic resonance (NMR) spectra were performed on $\mathrm{CDCl}_{3}$ in a Bruker $300 \mathrm{MHz}(300.13 \mathrm{MHz})$ equipment, model Avance III 300, using the $5 \mathrm{~mm}$ PABBO $\mathrm{BB}^{-}$probe. The ${ }^{1} \mathrm{H}$ NMR data are referenced to residual $\mathrm{CHCl}_{3}$ (7.27 ppm), and $2 \mathrm{D} \mathrm{NMR}\left({ }^{1} \mathrm{H}-{ }^{1} \mathrm{H}\right.$ correlation spectroscopy (COSY), ${ }^{1} \mathrm{H}-{ }^{13} \mathrm{C}$ heteronuclear single quantum coherence spectroscopy (HSQC), ${ }^{1} \mathrm{H}-{ }^{13} \mathrm{C}$ heteronuclear multiple bond correlation spectroscopy (HMBC)) with gradient were performed.

Infrared spectra were performed in an FTIR Shimadzu equipment, model Prestige-21, with a resolution of $4 \mathrm{~cm}^{-1}$, in a $\mathrm{KBr}$ matrix.

The UV-Vis spectra were obtained in acetonitrile as a solvent in a $1 \mathrm{~cm}$ quartz cell, using a Hewlett-Packard spectrophotometer, model HP 8453.

Fluorescence spectra were performed in a photon technology instrument (PTI) equipment, model Quanta Master 300, using a $1 \mathrm{~cm}$ four faces quartz cell, and a concentration of $1 \times 10^{-6} \mathrm{~mol} \mathrm{dm}^{-3}$ in deaerated acetonitrile.

Cyclic voltammetry experiments were conducted in an Autolab PGSTAT128N system. The compound $\left(1 \times 10^{-5} \mathrm{~mol} \mathrm{dm}^{-3}\right)$ was dissolved in acetonitrile, containing $0.1 \mathrm{~mol} \mathrm{dm}^{-3} \mathrm{TBAClO}_{4}$ as the electrolyte. A Pt disc (working electrode) and a Pt wire (auxiliary electrode) were employed for the measurements versus the $\mathrm{Ag} / \mathrm{Ag}^{+}$ reference electrode $\left(\mathrm{E}^{\circ}=0.503 \mathrm{~V}\right.$ versus $\mathrm{SHE}$ (standard hydrogen electrode) $){ }^{22}$

The AUTOLAB PGSTAT128N system investigated the spectroelectrochemical behavior in parallel with a spectrophotometer HP 8453 from Hewlett-Packard with a "diode array" detection. A quartz spectroelectrochemical cell with a $0.05 \mathrm{~cm}$ optic path was used. The electrodes system was composed of a gold minigrid as a working electrode, an $\mathrm{Ag} / \mathrm{Ag}^{+}$reference microelectrode, and a platine wire as the auxiliary electrode. The compound $\left(1 \times 10^{-5} \mathrm{~mol} \mathrm{dm}^{-3}\right)$ was dissolved in acetonitrile containing $\mathrm{TBAClO}_{4}\left(0.1 \mathrm{~mol} \mathrm{dm}^{-3}\right)$.

The chemical structures were designed using the software ChemBioDraw Ultra, ${ }^{23}$ version 11.01. All graphics and spectra were processed using the software OriginPro 8.5. ${ }^{24}$

\section{Syntheses}

Perylene-3,4,9,10-tetracarboxylic acid monoanhydride monopotassium carboxylate (1)

To $0.590 \mathrm{~g}(1.50 \mathrm{mmol})$ of perylene-3,4,9,10-tetra- 
carboxylic dianhydride and $0.358 \mathrm{~g}(6.37 \mathrm{mmol})$ of potassium hydroxide, $80 \mathrm{~mL}$ of deionized water were added. ${ }^{15,16}$ The solution was slowly heated for $2 \mathrm{~h}$ to $90{ }^{\circ} \mathrm{C}$, changing from red color to an orange solution (luminescent). After the solution turned to $90{ }^{\circ} \mathrm{C}$, the $\mathrm{pH}$ was measured $(\mathrm{pH}=10)$, and a dropwise titration was performed with $5.5 \mathrm{~mL}$ of $\mathrm{HCl} 1 \mathrm{~mol} \mathrm{dm}^{-3}$, until $\mathrm{pH}=4.5$, forming a bordeaux precipitate. The reaction remained for more than $1 \mathrm{~h}$, following by filtration of the bordeaux precipitate and dried in the desiccator. To the precipitate, $24 \mathrm{~mL}$ of ethanol and $14 \mathrm{~mL}$ of deionized water were added, and the solution was stored in the freezer for $20 \mathrm{~h}$. After $\mathrm{KCl}$ was filtrated off, the solution was concentrated to dryness into the rotary evaporator. After that, $24 \mathrm{~mL}$ of ethanol was added and stored in the freezer for $30 \mathrm{~h}$. A bordeaux solid was obtained. Yield: $0.583 \mathrm{~g}(86.34 \%)$; elem. anal. calcd. for $\mathrm{C}_{24} \mathrm{H}_{9} \mathrm{KO}_{7} \cdot 0.2 \mathrm{H}_{2} \mathrm{O}: \mathrm{C} 63.77, \mathrm{H} 2.10$, found: $\mathrm{C} 63.84$, $\mathrm{H} 1.93$; IR ( $\mathrm{KBr}) v / \mathrm{cm}^{-1} 1773(\nu \mathrm{C}=\mathrm{O}$ anhydride), 1719 $(v \mathrm{C}=\mathrm{O}$ conjugated to an aromatic ring $)$ and $1595(v \mathrm{C}=\mathrm{C}$ aromatic ring).

$\mathrm{N}$-(3-Propanol)perylene-3,4,9,10-tetracarboxylic3,4-(monoimide)anhydride-9,10-acid potassium carboxylate (2)

To $2.71 \mathrm{~mL}$ (33.4 mmol) of 3-amino-1-propanol diluted in $90 \mathrm{~mL}$ of water, $3.0 \mathrm{~g}(6.67 \mathrm{mmol})$ of perylene-3,4,9,10-tetracarboxylic acid monoanhydride monopotassium carboxylate $\mathbf{1}$ were added. The solution instantly turned green color, remained on $30{ }^{\circ} \mathrm{C}$ and agitation for $2 \mathrm{~h}$, then changed to reddish coloration. After, the solution was heated to $90^{\circ} \mathrm{C} / 2 \mathrm{~h}$, and $90 \mathrm{~mL}$ of $\mathrm{HCl}$ $1 \mathrm{~mol} \mathrm{dm}^{-3}$ were added, provided a red precipitate. This mixture remained on agitation at $85^{\circ} \mathrm{C} / 2 \mathrm{~h}$, giving a pasty red solid that was dried in vacuum for $2 \mathrm{~h}$, resulting in a purple powder, $3.19 \mathrm{~g}$ (98.4\% yield); elem. anal. calcd. for $\mathrm{C}_{26} \mathrm{H}_{13} \mathrm{NO}_{6} \cdot 1.5 \mathrm{H}_{2} \mathrm{O}$ : C 67.53, H 3.49, $\mathrm{N} 3.03$, found: C 67.71, H 3.39, N 3.52; IR (KBr) $v / \mathrm{cm}^{-1} 1729(\nu \mathrm{C}=\mathrm{O}$ carboxylic acid), 1693 and 1653 ( $\nu \mathrm{C}=\mathrm{O}$ amide), 1597 $(v \mathrm{C}=\mathrm{C}$ aromatic ring $), 1325(\delta \mathrm{C}-\mathrm{H}$ aliphatic $)$.

\section{5,11,17,23-Tetra(tert-butyl)-25,27-bis(3'-bromopropoxy)-} 26,28-(dihydroxy)calix[4]arene (3)

This compound was early synthesized and described in detail by us. ${ }^{25}{ }^{1} \mathrm{H}$ NMR $\left(300.13 \mathrm{MHz}, \mathrm{CDCl}_{3}\right) \delta 7.66$ (s, $2 \mathrm{H}, \mathrm{OH}), 7.06$ and $6.88(2 \mathrm{~s}, 8 \mathrm{H}, \mathrm{m}-\mathrm{Ar} H), 4.27$ and 3.36 (2d, spin $\mathrm{AB}$ system, ${ }^{2} J_{\mathrm{AB}} 12.95 \mathrm{~Hz}, 4 \mathrm{H}$ each, $\mathrm{ArCH}_{2} \mathrm{Ar}$ ), 4.12 and $4.02\left(2 \mathrm{t}, 8 \mathrm{H}, \mathrm{OCH}_{2} \mathrm{CH}_{2} \mathrm{CH}_{2} \mathrm{Br}\right), 2.55(\mathrm{~m}, 4 \mathrm{H}$, $\left.\mathrm{OCH}_{2} \mathrm{CH}_{2} \mathrm{CH}_{2} \mathrm{Br}\right), 1.28$ and $1.03\left(2 \mathrm{~s}, 36 \mathrm{H},{ }^{\mathrm{t}} \mathrm{Bu}\right)$; Yield: $4.61 \mathrm{~g}(67.10 \%) ; \mathrm{IR}(\mathrm{KBr}) v / \mathrm{cm}^{-1} 1578(\nu \mathrm{C}=\mathrm{C}$ aromatic ring), 1486 and $1363(\delta \mathrm{C}-\mathrm{H}$ aliphatic), 1202 and 1025 ( $v \mathrm{C}-\mathrm{O}$ aryl ether), 557 ( $v \mathrm{C}-\mathrm{Br}$ ).
5,11,17,23-Tetra(tert)butyl)-25-(3'-bromopropoxy)27-( $N$-[3'(3'-propoxy)propyl]perylene-(3', 4', 9', 10'-tetracarboxylic-3', 4'-(monoimide)anhydride-9', 10'-acid potassium carboxylate)-26,28-(dihydroxy)calix[4]arene (4)

To $1.90 \mathrm{~g}(1.34 \mathrm{mmol})$ of $5,11,17,23$-tetra(tert-butyl)25,27-bis(3'-bromopropoxy)-26,28-(dihydroxy)calix [4]arene 3, $1.50 \mathrm{~g}(3.34 \mathrm{mmol})$ of $N$-(3-propanol) perylene-3,4,9,10-tetracarboxylic-3,4-(monoimide) anhydride-9,10-acid potassium carboxylate 2 and $0.10 \mathrm{~g}$ (3.75 mmol) of $\mathrm{NaH}$, were added to $120 \mathrm{~mL}$ of DMF (previously distilled and stored with molecular sieves). The mixture was on agitation at $\mathrm{N}_{2}$ atm during $15 \mathrm{~min}$, and then heated to $70{ }^{\circ} \mathrm{C} / 72 \mathrm{~h}$. After being concentrated in a rotary evaporator, the product was extracted in dichloromethane and washed in water. The organic phase was concentrated, and purification by column chromatography was made using $\mathrm{SiO}_{2}$ (dichloromethane/ethyl acetate/methanol (5:4.5:0.5)). The red crystalline solid was obtained (yield $0.164 \mathrm{~g}(9.3 \%)$, elem. anal. calcd for $\mathrm{C}_{77} \mathrm{H}_{80} \mathrm{BrNO}_{10}$ : C 73.44, H 6.40, N 1.11, found: C 73.71, H 6.68, N 1.74; ${ }^{1} \mathrm{H}$ NMR (300.13 MHz, $\left.\mathrm{CDCl}_{3}\right) \delta 8.63,8.46$ (2d, 2H each, perylene-monoanhydride bonding to calixarene- $H_{2^{\prime}-5}$, and $\left.H_{1^{\prime}-6}, J 8.01 \mathrm{~Hz}\right), 8.42\left(\mathrm{~d}, 1 \mathrm{H}, H_{12^{\prime}}, J 8.02 \mathrm{~Hz}\right), 8.34,8.00$ and 7.63 (3d, $1 \mathrm{H}$ each, perylene-monoanhydride bonding to calixarene, $H_{7}, H_{8}$, and $H_{11}, J 8.02,8.01$ and $7.98 \mathrm{~Hz}$ ), $7.69(\mathrm{~s}, 2 \mathrm{H}, \mathrm{OH}), 7.08$ and $6.88(2 \mathrm{~s}, 8 \mathrm{H}, \mathrm{m}-\mathrm{ArH}), 4.88(\mathrm{tl}$, $2 \mathrm{H}, \mathrm{OCH}_{2} \mathrm{CH}_{2} \mathrm{CH}_{2} \mathrm{OAr}$ ), 4.75 (t, $2 \mathrm{H}, \mathrm{BrCH}_{2} \mathrm{CH}_{2} \mathrm{CH}_{2} \mathrm{OAr}$, $J 6.01 \mathrm{~Hz}), 4.37\left(\mathrm{t}, 2 \mathrm{H}, \mathrm{NCH}_{2} \mathrm{CH}_{2} \mathrm{CH}_{2} \mathrm{O}, J 6.32 \mathrm{~Hz}\right), 4.13$ and 4.22 (two overlapping t, $4 \mathrm{H}, \mathrm{ArOCH}_{2} \mathrm{CH}_{2} \mathrm{CH}_{2} \mathrm{Br}+$ ArOCH $\mathrm{CH}_{2} \mathrm{CH}_{2} \mathrm{O}$ ), 3.63 (sl, $2 \mathrm{H}, \mathrm{NCH}_{2} \mathrm{CH}_{2} \mathrm{CH}_{2} \mathrm{O}$ ), 4.27 and 3.34 (2d, spin $\mathrm{AB}$ system, $J_{\mathrm{AB}} 13.76 \mathrm{~Hz}, 4 \mathrm{H}$ each, $\left.\mathrm{ArCH}_{2} \mathrm{Ar}\right), 2.57\left(\mathrm{~m}, 2 \mathrm{H}, \mathrm{ArOCH}_{2} \mathrm{CH}_{2} \mathrm{CH}_{2} \mathrm{O}\right), 2.42(\mathrm{~m}, 2 \mathrm{H}$, $\left.\mathrm{ArOCH}_{2} \mathrm{CH}_{2} \mathrm{CH}_{2} \mathrm{Br}\right), 2.03\left(\mathrm{~m}, 2 \mathrm{H}, \mathrm{OCH}_{2} \mathrm{CH}_{2} \mathrm{CH}_{2} \mathrm{~N}\right), 1.30$ and $1.02\left(2 \mathrm{~s}, 36 \mathrm{H},{ }^{\mathrm{t}} \mathrm{Bu}\right) ;{ }^{13} \mathrm{C} \mathrm{NMR}\left(75.47 \mathrm{MHz}, \mathrm{CDCl}_{3}\right)$ $\delta 131.8,122.9,121.5,122.9,129.5,127.8,125.1,125.6$, 62.5, 60.8, 36.6, 72.2, 72.4, 58.7, 31.7, 29.3, 29.3, 30.9, 31.6, 30.9; $\mathrm{IR}(\mathrm{KBr}) v / \mathrm{cm}^{-1} 1724$ ( $\nu \mathrm{C}=\mathrm{O}$ carboxylic acid $)$, 1698 and 1653 ( $\nu \mathrm{C}=\mathrm{O}$ amide), $1597(\nu \mathrm{C}=\mathrm{C}$ aromatic ring), 1481 and 1363 ( $\delta \mathrm{C}-\mathrm{H}$ aliphatic), 1265, 1232 and 1019 $\left(v \mathrm{C}-\mathrm{O}\right.$ aryl ether), 1155 ( $v_{\mathrm{as}} \mathrm{C}-\mathrm{O}-\mathrm{C}$ aliphatic ether).

\section{Results and Discussion}

\section{Syntheses of perylene-derived calixarene ligands}

The condensation of 3-amino-1-propanol with the anhydride of $\mathbf{1}$ was carried out in aqueous media providing product $2 .{ }^{15}$

For 3 , the synthesis was made according to our previous work, ${ }^{25}$ obtaining a good yield $\left(67.1 \% \mathrm{Rf}=0.62\right.$ in $\mathrm{SiO}_{2}$ (hexane/ethyl acetate 4:1). 
Ligand 4 was obtained by a nucleophilic substitution reaction between the hydroxyl group of $\mathbf{2}$ and bromo of 3 (Figure 1). This synthesis was monitored by TLC in silica $60 \mathrm{~F}_{254}$. The reaction was completed after $72 \mathrm{~h}$, and the product purified using silica 60 , starting with eluent dichloromethane/ethyl acetate/methanol in the proportion (5:4.5:0.5). Subsequently, a more polar eluent mixture was used (dichloromethane/ethyl acetate/methanol in the ratio 4:5.5:0.5). A crystalline red solid was obtained, dried at reduced pressure, with low yield $(9.3 \%)$ because of the presence of sub-products and difficult solubility of starting materials. However, ligand $\mathbf{4}$ is easily soluble in organic solvents.

\section{Spectroscopic characterization of perylene-derived} calixarene ligands

The ligand 4 revealed the presence of ether groups formed by the union of $\mathbf{2}$ and $\mathbf{3}$, having all the 12 hydrogens from these groups attached to the calixarene (Figure 2), as well as the signals of the aromatic hydrogens of the perylene moiety. This main finding showed the binding of ligand $\mathbf{2}$ (containing perylene) to ligand $\mathbf{3}$ occurred by leaving only one of the bromine of this ligand $\mathbf{3}$. Consequently, only one perylene-derived group was added to calixarene. As evidence, a priori, it can be observed the $\mathrm{CH}_{2}$ aliphatic signals of ligand $\mathbf{3}$, before found in the<smiles>NCCCCO</smiles>

(1)<smiles></smiles>

(2)

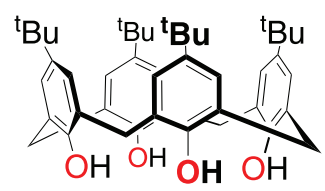

(i) $\mathrm{K}_{2} \mathrm{CO}_{3}$

(ii) $\mathrm{Br}\left(\mathrm{CH}_{2}\right)_{3} \mathrm{Br}$

$\mathrm{CH}_{3} \mathrm{CN}$

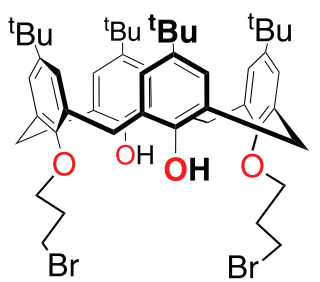

(3)
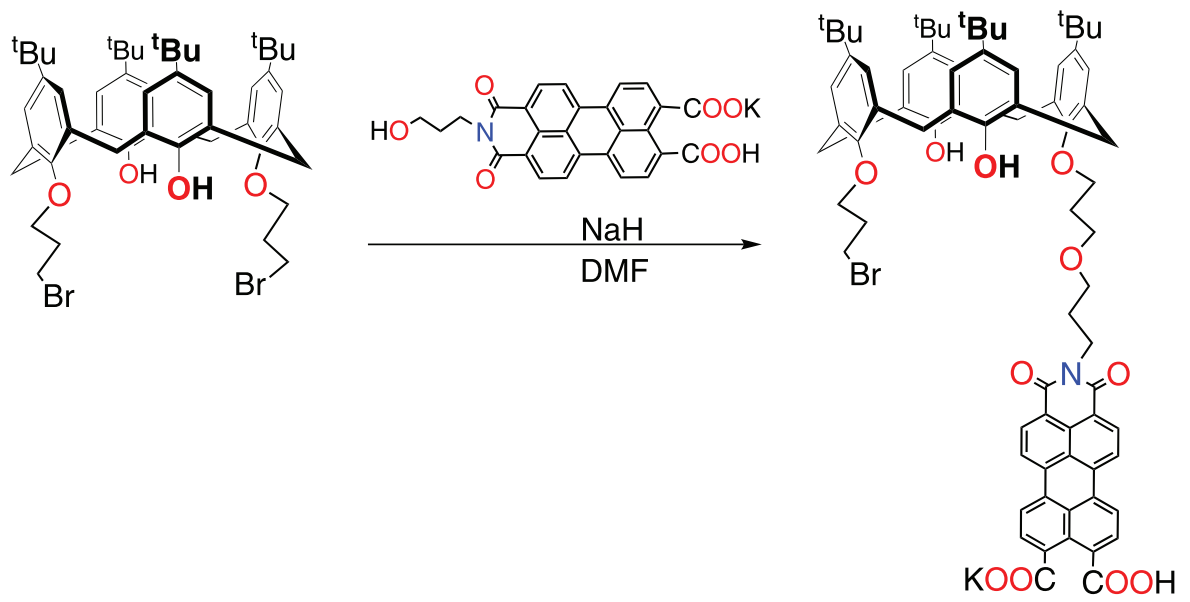

(4)

Figure 1. Schema of the syntheses of compounds $\mathbf{1}$ to $\mathbf{4}$. 
4.02 and $4.12 \mathrm{ppm}\left(2 \mathrm{t}, \mathrm{OCH}_{2} \mathrm{CH}_{2} \mathrm{CH}_{2} \mathrm{Br}\right.$ ), shifted to 4.13 and $4.75 \mathrm{ppm}$ for $\mathrm{OCH}_{2} \mathrm{CH}_{2} \mathrm{CH}_{2} \mathrm{Br}$ moiety and 4.22 and $4.87 \mathrm{ppm}$ for $\mathrm{ArOCH}_{2} \mathrm{CH}_{2} \mathrm{CH}_{2} \mathrm{O}$ moiety in the ligand 4. Likewise, it is possible to assign the two doublets at 8.63 and $8.46 \mathrm{ppm}$ with $2 \mathrm{H}$ each as the hydrogens closest to the (imide)anhydride (2', 5', and 1', 6' hydrogens, see the Figure S1, Supplementary Information (SI) section). However, because of the asymmetry of the perylene group, credited to the carboxylic acid and potassium carboxylate attached to 9' and 10' carbon ${ }^{12}$ (Figure S1), the hydrogens closest to these positions (12', 7', 8' and 11' hydrogens) respond differently as four doublets containing $1 \mathrm{H}$ each. Therefore, there are four doublets with $1 \mathrm{H}$ each, at $8.42 \mathrm{ppm}$ (overlapping to 8.46), 8.34, 8.00, and $7.63 \mathrm{ppm}$, integrating the eight hydrogens of perylene. These assignments were corroborated by COSY and HSBC two-dimensional correlations (Figures S2 and S3, SI section), including screening the principal carbon signals of this molecule (Table S1). HMBC two-dimensional correlations (for three-bond correlations along with weaker two and fourbond correlations) (Figure S4) helped to show the most strong correlations in the ligand $\mathbf{4}$, displaying, for instance, the $\mathrm{NCH}_{2} \mathrm{CH}_{2} \mathrm{CH}_{2} \mathrm{O}$ correlation, where $\mathrm{H}_{13}$, at $4.37 \mathrm{ppm}$ correlates to $\mathrm{C}_{15}$, at $58.7 \mathrm{ppm}$; also $-\mathrm{CH}_{2} \mathrm{NC}=\mathrm{Oimide}-$ the $\mathrm{H}_{13}$, at $4.37 \mathrm{ppm}$ correlates to $\mathrm{C}=$ Oimide at $164.4 \mathrm{ppm}$. Interestingly to perceive, although having a weak signal, a correlation between the proton at $4.22 \mathrm{ppm}\left(\mathrm{ArOC}_{18} \cdot \mathrm{H}_{2}\right.$ appendix) and the carbon at $127.6 \mathrm{ppm}$ (which match with a group $\mathrm{CH}_{\mathrm{ar}}$ from calixarene). This signal was tentatively assigned to the correlation of $\mathrm{H}_{18}$, (attached to carbon 27 of the calixarene matrix), to $m-C_{12} \mathrm{H}$ of calixarene. It is also possible to observe the strong correlations on the $\mathrm{H}$ and $\mathrm{C}$ from the calixarene matrix and the perylene moiety, as highlighted in Figure S4.

The synthesis of 1 from perylene-3,4,9,10-tetracarboxylic dianhydride is evidenced by two crucial bands (Figure 3). In Figure 3a, the core structure of the commercial perylene spectrum can be depicted by frequencies at $1595 \mathrm{~cm}^{-1}(\nu \mathrm{C}=\mathrm{C}$ aromatic ring $)$ and $1773 \mathrm{~cm}^{-1}(\nu \mathrm{C}=\mathrm{O}$ anhydride). The spectrum of $\mathbf{1}$ (Figure $3 \mathrm{~b}$ ) includes the band at $1595 \mathrm{~cm}^{-1}$, indicating the reaction, as expected, does not affect the core structure of perylene, just as part of $\mathbf{1}$ continues with $v \mathrm{C}=\mathrm{O}$ anhydride at $1773 \mathrm{~cm}^{-1}$ as observed in the scheme of Figure 1. However, a shift of the carbonyl band was observed at $1719 \mathrm{~cm}^{-1}$, in a specific region of carboxylic acids carbonyls conjugated to aromatic rings, such as the product formed. It is also interesting to note that the carboxylic acid band is at a lower value than regular due to the intramolecular hydrogen bond between the carboxylic acid hydrogen and the carboxylate oxygen.

The development of $\mathbf{2}$ from $\mathbf{1}$ is verified by the presence of the amide stretching bands at 1693 and $1653 \mathrm{~cm}^{-1}$ and angular deformation of aliphatic $\mathrm{CH}$ bonds at $1325 \mathrm{~cm}^{-1}$ of

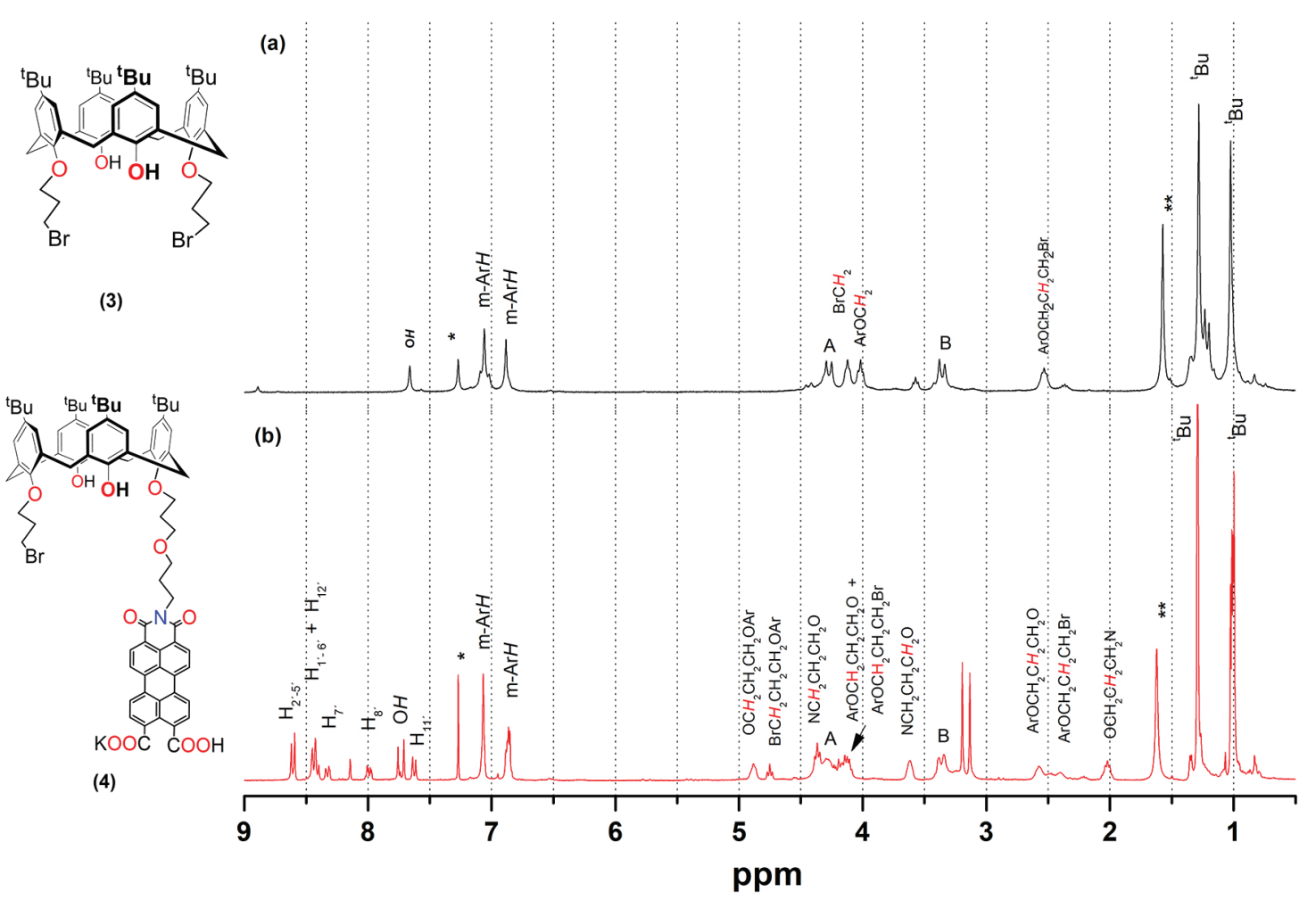

Figure 2. ${ }^{1} \mathrm{H}$ NMR (300.13 MHz) spectra of (a) $\mathbf{3}$ and (b) ligand $\mathbf{4}$ on the range 9.0-0.5 ppm in $\mathrm{CDCl}_{3} .{ }^{*} \mathrm{CDCl}_{3}$ signal, $* *$ water signal from solvent. 


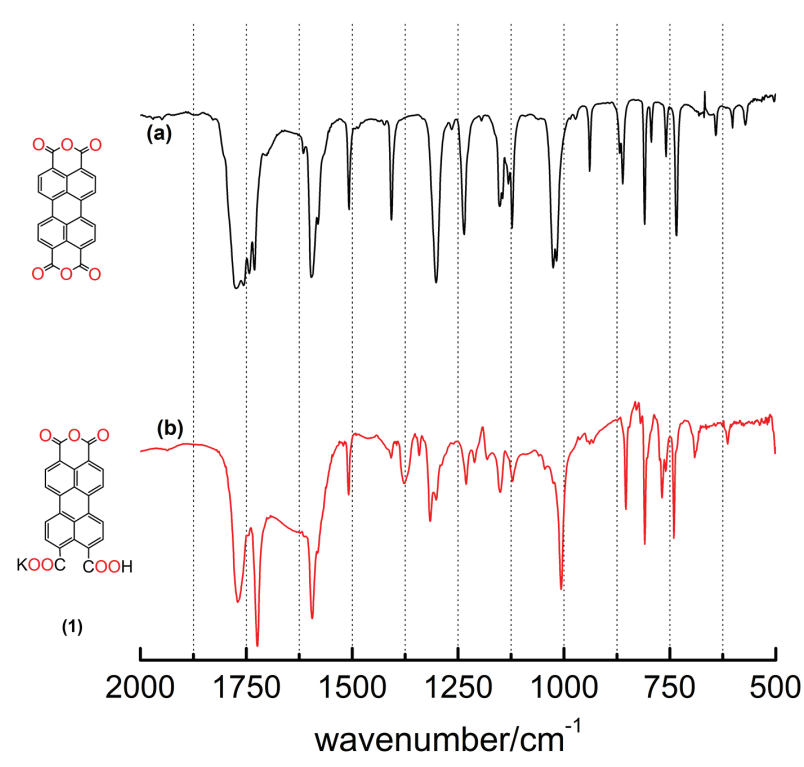

Figure 3. IR spectra of (a) perylene-3,4,9,10-tetracarboxylic dianhydride and (b) 1 on the range $2000-500 \mathrm{~cm}^{-1}$ in the $\mathrm{KBr}$ matrix.

the alkyl chain connecting nitrogen to alcohol (Figure 4a). The frequencies at $1578 \mathrm{~cm}^{-1}(\nu \mathrm{C}=\mathrm{C}$ aromatic ring $) ; 1486$ and $1363 \mathrm{~cm}^{-1}\left(\delta \mathrm{C}-\mathrm{H}\right.$ aliphatic); 1025 and $1202 \mathrm{~cm}^{-1}(v \mathrm{C}-\mathrm{O}$ aryl ether) and $557 \mathrm{~cm}^{-1}(v \mathrm{C}-\mathrm{Br})$ (Figure $\left.4 \mathrm{~b}\right)$, supported the structure of 3 . The frequencies observed at $1724 \mathrm{~cm}^{-1}$ ( $v \mathrm{C}=\mathrm{O}$ carboxylic acid), 1698 and $1653 \mathrm{~cm}^{-1}(\nu \mathrm{C}=\mathrm{O}$ amide), $1597 \mathrm{~cm}^{-1}\left(\nu \mathrm{C}=\mathrm{C}\right.$ aromatic ring), 1481 and $1363 \mathrm{~cm}^{-1}$ $\left(\delta \mathrm{C}-\mathrm{H}\right.$ aliphatic), 1019, 1232 and $1265 \mathrm{~cm}^{-1}(\nu \mathrm{C}-\mathrm{O}$ aryl ether), $1155 \mathrm{~cm}^{-1}\left(v_{\mathrm{as}} \mathrm{C}-\mathrm{O}-\mathrm{C}\right.$ aliphatic ether) (Figure $4 \mathrm{c}$ ), show product $\mathbf{4}$ has the same bands as the precursors, as expected, but with slightly different wavenumbers, as a consequence of the interactions between the groups. Furthermore, the functionalization of the calixarene leads to the formation of an aliphatic ether whose band is observed at $1155 \mathrm{~cm}^{-1}\left(v_{\mathrm{as}} \mathrm{C}-\mathrm{O}-\mathrm{C}\right.$ ether $)$.

\section{Luminescence-emission and excitation spectra}

The emission spectrum of $\mathbf{1}$ (Figure 5a) showed bands at 498,539 and $586 \mathrm{~nm}$ (excitation wavelength, $\lambda_{\text {exc }}=458 \mathrm{~nm}$ ) and the excitation spectrum revealed three bands at 426 , 455 and $489 \mathrm{~nm}$ (emission wavelength, $\lambda_{\mathrm{em}}=539 \mathrm{~nm}$ ), which is a specular image of the emission spectrum. In both situations, these bands are assigned as $\pi \rightarrow \pi *$ transitions from the perylene structure. The first emission band at $498 \mathrm{~nm}$ is assigned to the transition $S_{1} \rightarrow S_{0}$ from the singlet excited state to the singlet ground state. The other bands are due to the vibrational levels of the excited to the fundamental singlet state. The well-defined structure of the spectrum can be ascribed to the vibrational energy levels of the fundamental and excited singlet states.

Similarly, the emission spectrum of 2 (Figure $5 \mathrm{~b}$ ) presented bands at 531,573 , and $620 \mathrm{~nm}$, and the excitation spectrum showed three bands at 445, 477, and $508 \mathrm{~nm}$ as a specular image of the emission spectrum. The bands are also ascribed to the transitions $\pi \rightarrow \pi *$ of perylene structure, and are very similar to transitions of $\mathbf{1}$, with small displacements in the position of the ligand bands.

The emission spectrum of ligand 4 (Figure $5 c$ ) exhibited one band at $540 \mathrm{~nm}$ and a shoulder at $577 \mathrm{~nm}$, and the excitation spectrum displayed three bands at 464,479 , and $490 \mathrm{~nm}$. It is curious that the bands, also attributed to the transitions $\pi \rightarrow \pi *$ of perylene structure, are wider in the system in which the perylene is attached to calixarene.

Comparing to its precursor, a significant change in absorption and emission spectra occurred since the emission spectrum is sensitive to the structure of the compound. In this case, the structure was highly modified due to its coupling to a large group (the calixarene). In this situation, it is not observed a specular image for the

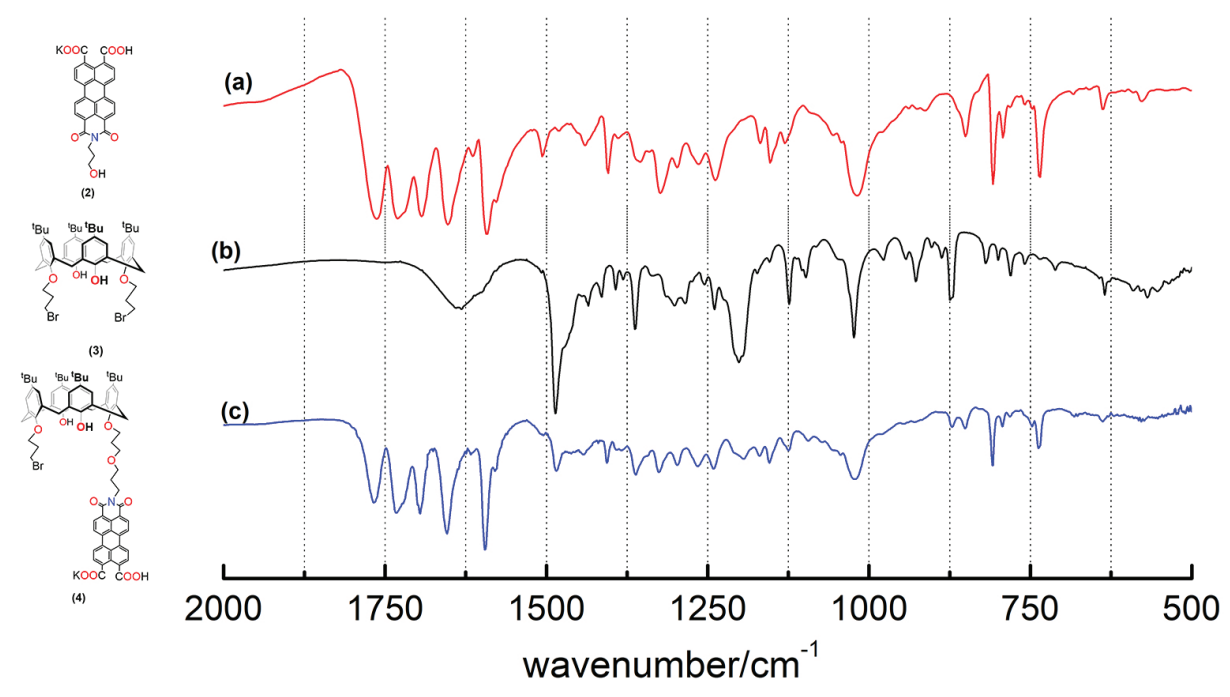

Figure 4. IR spectra of (a) 2, (b) 3 , and (c) ligand 4 on the range $2000-500 \mathrm{~cm}^{-1}$ in the $\mathrm{KBr}$ matrix. 


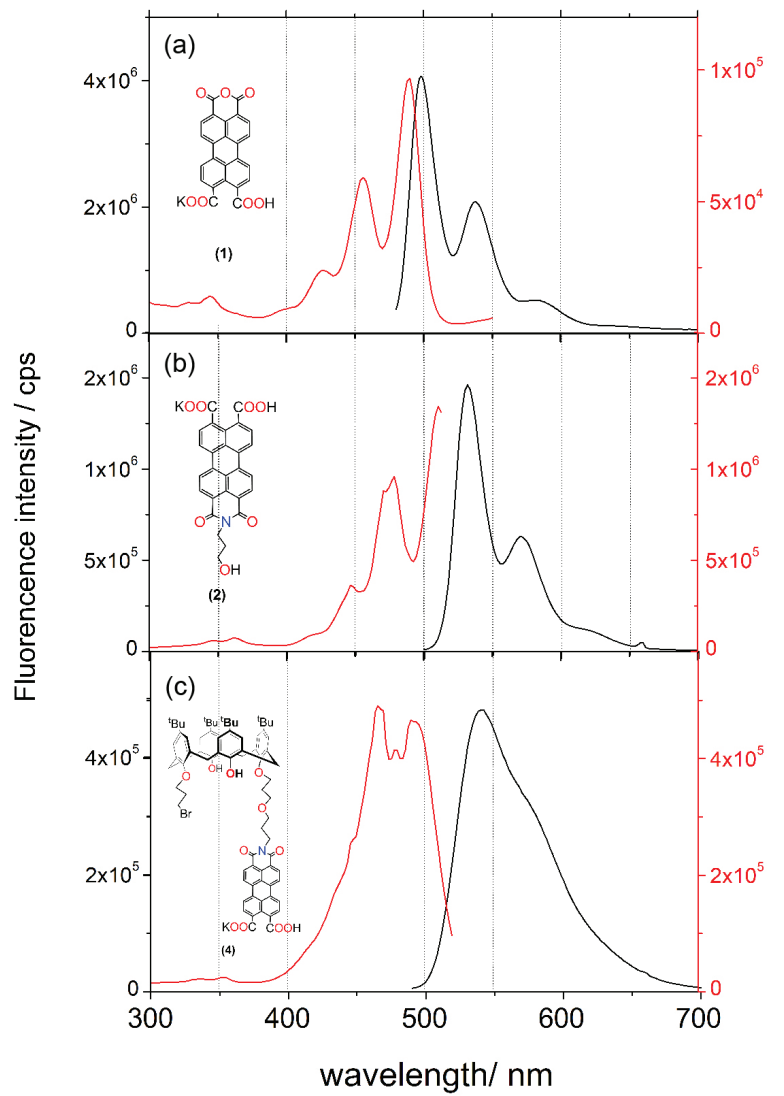

Figure 5. Excitation (left, in red) and emission (right, in black) spectra on 300-700 nm range at $1 \times 10^{-6} \mathrm{~mol} \mathrm{dm}^{-3}$ in acetonitrile: (a) ligand 1 $\left(\lambda_{\text {exc }}=458 \mathrm{~nm}\right.$ and $\lambda_{\mathrm{em}}=498,539$ and $\left.586 \mathrm{~nm}\right)$; (b) ligand $2\left(\lambda_{\mathrm{exc}}=480 \mathrm{~nm}\right.$ and $\lambda_{\mathrm{em}}=531,573$ and $\left.620 \mathrm{~nm}\right)$; (c) ligand $4\left(\lambda_{\mathrm{exc}}=470 \mathrm{~nm}\right.$ and $\left.\lambda_{\mathrm{em}}=540 \mathrm{~nm}\right)$.

excitation and emission spectra. This statement can be explained by a rearrangement in the excited state core geometry of chromophore owing to the long lifetime of the $S_{1}$ state. ${ }^{26,27}$

Stokes shifts were determined by the wavelength differences of the most intense excitation and emission bands (corresponding to each other's specular image) for each of the ligands. The results are shown in Table 1. It is pleasant to note that ligand $\mathbf{4}$ has a higher Stokes displacement relative to ligands $\mathbf{1}$ and $\mathbf{2}$, which increases with coupling to the calixarene structure and is advantageous for biological marker applications. Comparing also to perylene ligands ${ }^{17}$ and perylene-imide upper-rim calixarenes ${ }^{27,28}$ from literature is noticeable that the Stokes shifts are more remarkable as the perylene group is attached to the calixarene through ethers or alkyl groups.

Quantum yields of the compounds were calculated according to equation $1^{29}$ where $\varphi_{X}$ is the sample quantum yield to be determined, $\varphi_{\mathrm{S}}$ is the standard quantum yield, $A_{X}$ is the area of the sample emission spectrum curve, $A_{S}$ is the area of the standard emission spectrum curve, $\mathrm{Abs}_{\mathrm{S}}$ is the standard absorption in the absorption spectrum for
Table 1. Stokes shifts for excitation and emission bands

\begin{tabular}{lcccc}
\hline Ligand & $\lambda_{\text {exc }} / \mathrm{nm}$ & $\lambda_{\mathrm{em}} / \mathrm{nm}$ & $\begin{array}{c}\text { Stokes } \\
\text { shift } / \mathrm{nm}\end{array}$ & Reference \\
\hline $\mathbf{1}$ & 489 & 498 & 9 & this work \\
$\mathbf{2}$ & 508 & 531 & 23 & this work \\
$\mathbf{4}$ & 490 & 540 & 50 & this work \\
PDI 1 $^{\mathrm{a}}$ & 527 & 534 & 7 & 17 \\
Py-c-PBI $^{\mathrm{b}}$ & 525 & 531 & 6 & 27 \\
PDC $^{\mathrm{c}}$ & 540 & 555 & 13 & 28 \\
\hline
\end{tabular}

$\lambda_{\text {exc }}$ : excitation wavelength; $\lambda_{\text {em }}$ : emission wavelength; ${ }^{a} P D I$ 1: perylene diimide 1 (1 = R: 2,6-diisopropylphenyl (DIP)); ${ }^{17}$ by-c-PBI: carboxamidopyrene unit (Py) linked to a calix[4]arene (c) functionalized with PBI ("perylene orange"); ${ }^{27}$ cPDC: bis-perylene bis-dendro calix[4]arene. ${ }^{28}$

the excitation wavelength, $\mathrm{Abs}_{\mathrm{X}}$ is the sample absorption in the absorption spectrum for the excitation wavelength, and $\mathrm{n}_{\mathrm{s}}{ }^{2}$ and $\mathrm{n}_{\mathrm{x}}{ }^{2}$ are the refractive indices of the solvents used for standard and sample dilution, respectively.

$\varphi_{\mathrm{x}}=\varphi_{\mathrm{S}} \times \frac{\mathrm{A}_{\mathrm{x}}}{\mathrm{A}_{\mathrm{S}}} \times \frac{\mathrm{Abs}_{\mathrm{S}}}{\mathrm{Abs}_{\mathrm{x}}} \times \frac{\mathrm{n}_{\mathrm{S}}{ }^{2}}{\mathrm{n}_{\mathrm{x}}{ }^{2}}$

All quantum yields were calculated based in rhodamine $6 \mathrm{G}$, which has a $\varphi_{\mathrm{S}}=0.94^{30}$ in acetonitrile, and quinine sulphate which has a $\varphi_{\mathrm{S}}=0.53 .{ }^{31}$ For calculations using rhodamine $6 \mathrm{G}$ as standard, the solvent refractive index is the same for both sample and standard, as they were dissolved in acetonitrile, $\mathrm{n}_{\text {acetonitrile }}=1.3442 .{ }^{32}$ For calculations using quinine sulphate, which was dissolved in water with solely $0.05 \mathrm{~mol} \mathrm{dm}^{-3}$ sulfuric acid, only the refractive index of water was considered $\left(\mathrm{n}_{\text {water }}=1.3325\right){ }^{33}$

The areas of the curves for the standard and sample emission spectra were calculated using the Origin software $^{24}$ integration tool, and are found in Table 2, as well as the values of $\lambda_{\text {exc }}$, and the quantum yields calculated using rhodamine $6 \mathrm{G}$ as standard $\left(\varphi_{R}\right)$ and also quinine sulphate as standard $\left(\varphi_{\mathrm{QS}}\right)$, employing equation 1 .

Quantum yield values obtained using quinine sulfate are not very close to the values obtained using rhodamine $6 \mathrm{G}$, possibly due to the approximation of the refractive index. As the refractive index is the same for the calculation made with rhodamine $6 \mathrm{G}$, the quantum yield values obtained using rhodamine $6 \mathrm{G}$ as standard are the most reliable.

Regarding $\mathbf{2}$ and ligand $\mathbf{4}$ that have 3,4,9,10-perylene tetracarboxylic dianhydride as starting material chromophore $\left(\varphi_{\mathrm{S}}\right.$ ca. 1$)$, it is possible to realize that as the chromophore group undergoes modifications the quantum yield decreases.

The quantum yield of $\mathbf{2}$ drops compared to the starting chromophore because the electron density of 
Table 2. Quantum yields of standard and samples

\begin{tabular}{|c|c|c|c|c|c|}
\hline Sample & $\lambda_{\text {exc }} / \mathrm{nm}$ & $\lambda_{\mathrm{em}} / \mathrm{nm}$ & Area & $\varphi_{\mathrm{R}}$ & $\varphi_{\mathrm{QS}}$ \\
\hline Rhodamine 6G & 524 & - & $1.765 \times 10^{8}$ & $0.94^{28}$ & \\
\hline Quinine sulfate & 347 & - & $1.240 \times 10^{8}$ & & $0.53^{29}$ \\
\hline 2 & 480 & 531 & $6.403 \times 10^{7}$ & 0.57 & 0.37 \\
\hline 4 & 470 & 540 & $3.446 \times 10^{7}$ & 0.31 & 0.20 \\
\hline PDI 1 ${ }^{\text {a } 17}$ & 527 & 534 & - & 0.99 & - \\
\hline $\mathrm{PBI}^{\mathrm{b}} 27$ & - & - & - & 0.03 & - \\
\hline Py-c-PBI ${ }^{\mathrm{c}} 27$ & 470 & 531 & - & $5 \times 10^{-4}$ & - \\
\hline
\end{tabular}

$\lambda_{\text {exc }}$ : excitation wavelength; $\lambda_{\text {em }}$ : emission wavelength; $\varphi_{\mathrm{R}}:$ quantum yield based on rhodamine; $\varphi_{\mathrm{QS}}:$ quantum yield based on quinine sulfate; ${ }^{\text {PPDI }} 1:$ perylene diimide 1 (1 = R: 2,6diisopropylphenol (DIP)); ${ }^{17}$ bBI: "perylene orange"; 27 cPy-c-PBI: carboxamido-pyrene unit (Py) linked to a calix[4]arene ${ }^{27}$ functionalized with PBI ("perylene orange"). ${ }^{27}$

the aromatic ring is attracted to the amine. However, this ligand still has a considerable quantum yield value and is comparable to the traditional standards, according to the IUPAC Photoluminescence Standards guide. ${ }^{31}$ Nevertheless, attaching ligand $\mathbf{2}$ to a calixarene, ligand 4 was achieved, acquiring a decrease of about $50 \%$ in the quantum yield. This fact is owing to the calixarene that quenches the chromophore quantum yield, probably through a mechanism of electron transfer from perylene to calixarene. It has been observed in the literature that perylene-diimides, PDI, ${ }^{12}$ exhibits clear evidence of a strong effect of solvents, mainly due to polarity, associating this quenching to a photoinduced electron transfer process. Py-c-PBI (carboxamido-pyrene unit (Py) linked to a calix[4] arene functionalized with PBI), ${ }^{27}$ a calixarene functionalized directly in the upper position with perylene, its emission quantum yield decays about 620 times less than ligand $\mathbf{4}$, against ten times the c-PBI (calix[4]arene functionalized with PBI) monosubstituted ligand. Apart from solvent effects (all are in acetonitrile), they suggest an additional pyrene in Py-c-PBI also contributes to quenching the emission quantum yield. ${ }^{27}$

The decrease of quantum yield for the ligand $\mathbf{4}$, however, has been accompanied by a considerable increase in the solubility of the chromophore, which has grown as the synthetic route reactions were progressively performed. Thus, ligand $\mathbf{4}$ shows a satisfactory quantum yield with a high appeal because of its better solubility.

Comparing to 5,11,17,23-tetra(tert-butyl)25,27-bis(1,8-naphtylimideethoxy)-26,28-(dihydroxy) calix[4]arene, whose quantum yield is $0.02,{ }^{34}$ two comparisons can be made for ligand 4 concerning its quantum yield. The first one is that both exhibit luminescence quenching to some degree caused by the calixarene structure, which should be lower in the case of ligand 4 . That fact is attributable to the greater perylene distance from the macrocycle, as two ether groups connect them. The other comparison refers to the conjugation of chromophores. Ligand $\mathbf{4}$ has five conjugated aromatic rings, which compared to 5,11,17,23-tetra(tert-butyl)25,27-bis(1,8-naphtylimideethoxy)-26,28-(dihydroxy) calix[4]arene, increases the quantum yield significantly. Such combined effects lead to enhancement by about fifteen-fold in quantum yield of ligand 4 .

\section{Molar absorption coefficient and brightness}

In order to calculate the brightness parameter described above, employed to evaluate biological markers, the molar absorption coefficient of ligand $\mathbf{4}$ was calculated. For this, an electronic spectrum of ligand $\mathbf{4}$ with a concentration of $1 \times 10^{-5} \mathrm{~mol} \mathrm{dm}^{-3}$ was obtained and calculated by isolating the molar absorption coefficient in Beer's Law (equation 2) in which $\mathrm{A}$ is the absorbance, $\varepsilon$ is the molar absorption coefficient (in $\mathrm{dm}^{3} \mathrm{~mol}^{-1} \mathrm{~cm}^{-1}$ ), 1 is the optical path of the cuvette, which in this case equals $1 \mathrm{~cm}$, and $\mathrm{C}$ is the sample concentration (in $\mathrm{mol} \mathrm{dm}^{-3}$ ).

$\mathrm{A}=\varepsilon \times 1 \times \mathrm{C}$

As of the molar absorption coefficient values calculated for the three bands observed in the electronic spectrum of the compound $\mathbf{4}$, the brightness values were calculated using equation 3 . These results are shown in Table 3.

Brightness $=\varepsilon \times \varphi$

According to the brightness values, ${ }^{20,21}$ the compound can be classified as brightness 1 to 2 , and it can be used for applications in this range.

Electrochemical and spectroelectrochemical behavior of perylene-derived calixarene ligand

Cyclic voltammetry of ligand $\mathbf{4}$ depicted a reversible pair on the -0.75 to $-1.60 \mathrm{~V}$ range vs $\mathrm{Ag} / \mathrm{Ag}^{+}$(Figure 6), 
Table 3. Molar absorption coefficient and brightness of ligand 4

\begin{tabular}{lcccc}
\hline$\lambda_{\text {exc }} / \mathrm{nm}$ & Abs & $\varepsilon /\left(\mathrm{dm}^{3} \mathrm{~mol}^{-1} \mathrm{~cm}^{-1}\right)$ & Brightness intensity & Brightness $^{21}$ \\
\hline 439 & 0.58 & 57689 & 17646 & 1 \\
470 & 0.95 & 95334 & 29160 & 1 \\
499 & 1.11 & 110830 & 33900 & 2 \\
\hline
\end{tabular}

$\lambda_{\text {exc }}$ : excitation wavelength; Abs: absorbance; $\varepsilon$ : molar absorptivity coefficient.

resulting in a half-wave potential, $\mathrm{E}_{1 / 2}=-1.17 \mathrm{~V}$ $\left(\mathrm{E}_{\mathrm{pa}}=-1.12 \mathrm{~V}\right.$ and $\left.\mathrm{E}_{\mathrm{pc}}=-1.22 \mathrm{~V}\right)$.

The reversible character of this process is evidenced by the $i_{a} / i_{c}$ peaks, which results in 1.12 , approximately 1,35 and the difference between the positive and negative potentials $(\Delta \mathrm{Epp})$ is approximately $59 \mathrm{mV}$ and independent of sweep speed. In this case, the difference $\Delta \mathrm{Epp}$ is about $100 \mathrm{mV}$, but there are no significant differences between sweep speeds. In this sense, the process can be interpreted as reversible due to non-dependence on sweep speeds. The difference in the calculated $\Delta$ Epp related to actual value is attributed to the ohmic drops of the electrodes in the system. The calculated half-wave potentials remain invariable at sweep speed. Another way to attest to the process reversibility is through the relationship between the peak current versus the square root of the sweep speed. When the process is reversible, both connections between the anodic (or cathodic) peak current as a function of the square root of the sweep velocity are linear. Such a relationship is not valid for irreversible processes. As observed in the inset of Figure 6, the relationships mentioned above are correct for the described process, with coefficients of determination of 0.99303 for anodic peak current.
A study on the spectroelectrochemical behavior of ligand $\mathbf{4}$ was performed. From the voltammogram previously obtained (Figure 6), the electronic spectra of compound $\mathbf{4}$ were obtained applying potentials from -1.03 to $-1.33 \mathrm{~V}$ vs $\mathrm{Ag} / \mathrm{Ag}^{+}$(Figure 7).

The first spectrum is like the spectrum in which there is no potential application. The main absorption bands present are the bands at 473 and $499 \mathrm{~nm}$, which correspond to the absorption bands of the chromophore. As the potential is applied, a band at $627 \mathrm{~nm}$ appears, and bands at 473 and $499 \mathrm{~nm}$ decay. This process corresponds to the generation of the reduced chromophore species as the potential is applied. The reduction affects the electron displacement of the chromophore structure, and thus the absorption energy, shifting the absorption band to $627 \mathrm{~nm}$. The decaying in the original bands at 473 and $499 \mathrm{~nm}$ and the appearance at $627 \mathrm{~nm}$, produces an isosbestic point at $540 \mathrm{~nm}$, which shows that there is only one process in the system, i.e., only a single electron electrochemical process (reduction process). The number of electrons involved in the reversible process was calculated from the absorbance values obtained by the spectrum. The $\log \left(\mathrm{A}_{2}-\mathrm{A}_{1} / \mathrm{A}_{3}-\mathrm{A}_{2}\right)$ vs $E(V)$ plot (the inset of Figure 7), results in a linear graphic.

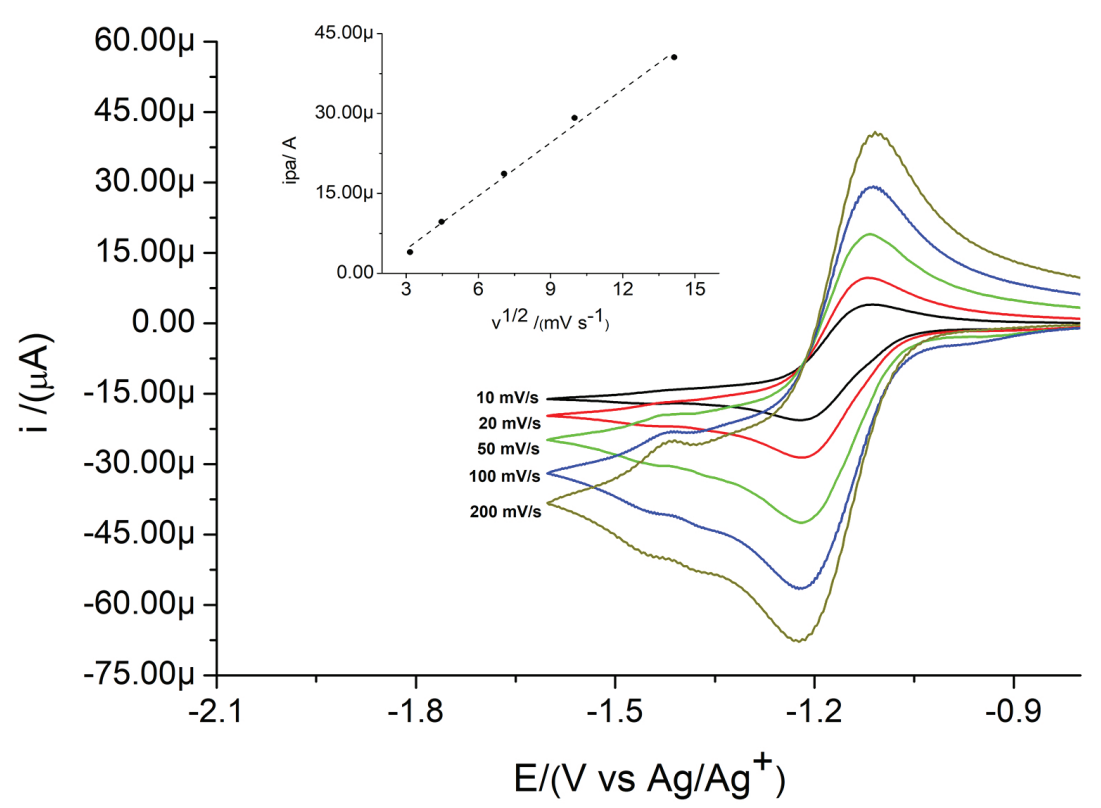

Figure 6. Cyclic voltammograms of the ligand $4\left(1 \mathrm{mmol} \mathrm{dm}^{-3}\right)$ in acetonitrile solution, $0.10 \mathrm{~mol} \mathrm{dm}^{-3}$ tetraethylammonium perchlorate, at several scan rates, on -0.75 to $-1.60 \mathrm{~V} v s \mathrm{Ag} / \mathrm{Ag}^{+}$. Inset: linear graphic based on $\mathrm{i}_{\mathrm{pa}} v s \mathrm{v}^{1 / 2}$. 


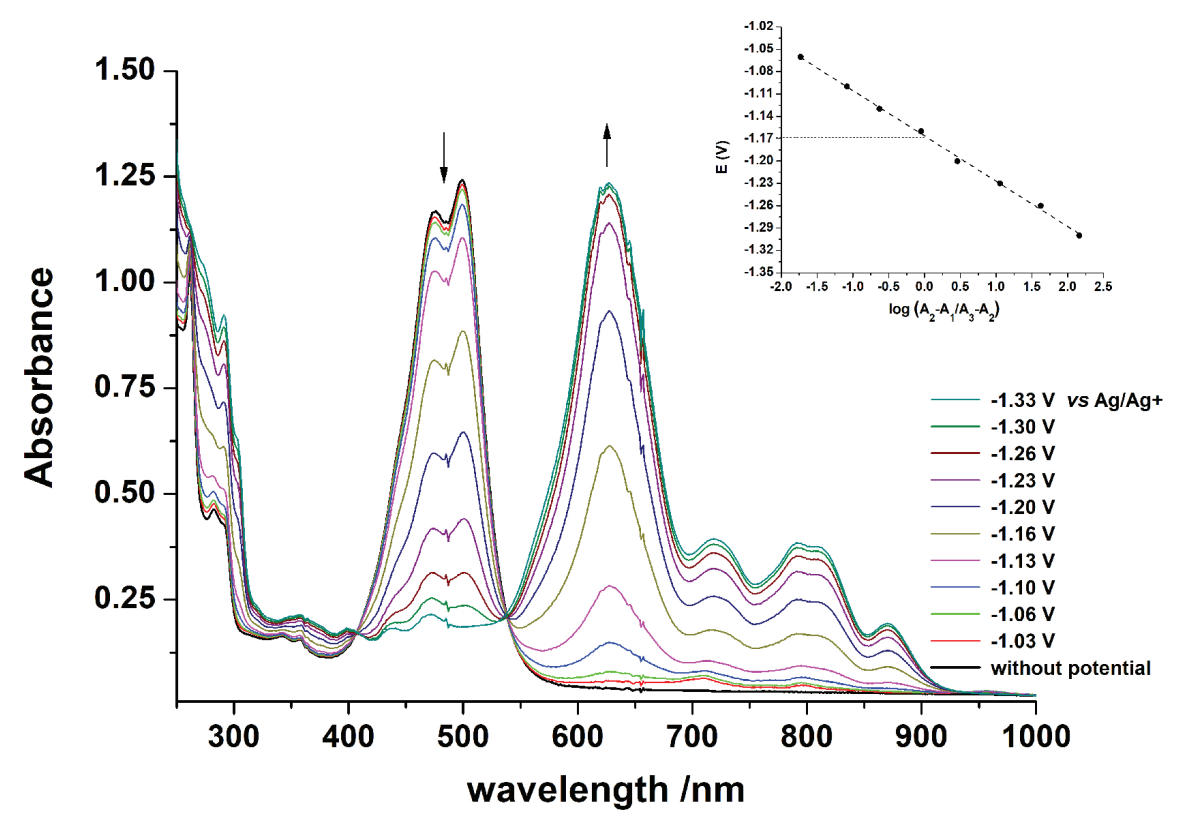

Figure 7. UV-Vis spectroelectrochemical behavior of ligand $\mathbf{4}\left(1 \times 10^{-5} \mathrm{~mol} \mathrm{dm}^{-3}\right)$ in acetonitrile solution, $0.10 \mathrm{~mol} \mathrm{dm} \mathrm{m}^{-3}$ tetraethylammonium perchlorate. Reduction process at negative potentials, -1.03 to $-1.30 \mathrm{~V} v s \mathrm{Ag} / \mathrm{Ag}^{+}$, monitored by the decay of the absorption band at 473 and $499 \mathrm{~nm}$. Inset: linear graphic based on $\mathrm{E}(\mathrm{V})$ vs $\log \left(\mathrm{A}_{2} \mathrm{~A}_{1} / \mathrm{A}_{3} \mathrm{~A}_{2}\right)$.

Here, $A_{1}$ is the absorbance of the peak without applied potential; $\mathrm{A}_{2}$ is the absorbance of the peak at the applied potential, and $\mathrm{A}_{3}$ is the absorbance of the peak at the last applied potential. The linear function equation, calculated using Origin software, ${ }^{24}$ provides an angular coefficient value equal to $0.06085 \mathrm{~V}$ and a linear coefficient value equal to $-1.166\left(\mathrm{R}^{2}=0.99802\right)$, indicating excellent linearity between the data. The angular coefficient value obtained by the equation corresponds to the value $0.0592 / \mathrm{n}$ of the Nernst equation (equation 4). In this equation, $\mathrm{n}$ is the number of electrons involved in the process $\left(0.0592 \mathrm{~J} \mathrm{~mol}^{-1}\right.$ is the product of the constant of the ideal gases, $\mathrm{R}=8.315 \mathrm{~J} \mathrm{~K}^{-1} \mathrm{~mol}^{-1}$, by temperature, $\mathrm{T}=298 \mathrm{~K}$ ). Using the Nernst equation, it is possible obtaining the $\mathrm{n}=0.97$, which corresponds to only one electron transfer for the redox process of $\mathbf{4}$. The linear coefficient value corresponds to a $\mathrm{E}^{0}=-1.166 \mathrm{~V}$, as well as $\mathrm{E}_{1 / 2}=-1.17 \mathrm{~V}$ vs $\mathrm{Ag} / \mathrm{Ag}^{+}$, obtained by cyclic voltammetry.

$\mathrm{E}=\mathrm{E}^{0}-\frac{0.0592}{\mathrm{n}} \log \frac{\mathrm{A} 2-\mathrm{A} 1}{\mathrm{~A} 3-\mathrm{A} 2}$

This redox process of one electron is characteristic of perylene-imide and naphtalimide structures, where there is the establishment of a radical anion in only one of the carbonyls. According to Lee, ${ }^{36}$ in the presence of diimides, two reversible redox processes will occur, both involving the transfer of only one electron relating to the formation of a radical anion in only one of the carbonyls. As the calculation and the spectra indicate, for ligand $\mathbf{4}$, there is only one imide in the ligand, demonstrating the other carbonyls, are found as carboxylic acid and carboxylate, which go through different processes not observed in the voltammogram.

\section{Conclusions}

A novel perylene-based calixarene ligand $\mathbf{4}$ was synthesized and characterized by NMR, IR, UV-Vis, elemental analysis. Based on the electrochemistry data, it is possible to observe a very stable ligand with a well-behaved reversible redox process. This behavior is characteristic of the monoelectronic redox process of perylene-imide and naphtalimide structures, involving the transfer of only one electron relating to the formation of a radical anion in only one of the carbonyls. Furthermore, 4 presents a broad emission shifted to $540 \mathrm{~nm}$ based on its precursor $\mathbf{2}$, shown at $531 \mathrm{~nm}$, and $\mathbf{4}$ depicted a quantum yield $(\phi=0.31)$ less than $2(\phi=0.57)$, indicating that association with calixarene slightly decreases quantum yield. Although the lower quantum yield for ligand $\mathbf{4}$ compared to the perylene group, it has been accompanied by an increase in its solubility, which supplies to the system better applicability in lightemitting devices, like OLEDs, and especially in biological markers. Studies on the application of $\mathbf{4}$ in the luminescent materials are in progress and will be reported in due time.

\section{Supplementary Information}

Supplementary data are available free of charge at http://jbcs.sbq.org.br as PDF file. 


\section{Acknowledgments}

The authors gratefully acknowledge Brazilian agencies FAPESP (process No. 2015/20485-4), CNPq, and CAPES for their financial support. G.M.O. thanks FAPESP (process No 2017/15083-0) for the scholarship. Also, the authors acknowledge the LQSN (Laboratório de Química Supramolecular e Nanotecnologia) for consent to the use of luminescence equipment.

\section{References}

1. Perrin, R.; Lamartine, R.; Perrin, M.; Pure Appl. Chem. 1993, 65, 1549.

2. Silva, E. D.; Lazar, A. N.; Coleman, A.W.; J. Drug Delivery Sci. Technol. 2004, 14, 3.

3. Sliwa, W.; Deska, M.; ARKIVOC 2011, 496.

4. Gutsche, C. D.; Calixarenes: An Introduction; RSC Publishing: Cambridge, 2008.

5. Gutsche, C. D.; Stoddart, J. F. In Monographs in Supramolecular Chemistry; RSC Publishing: Cambridge, 1989.

6. Gutsche, C. D.; Dhawan, B.; No, K. H.; Mutbukrishman, R.; J. Am. Chem. Soc. 1981, 103, 3782.

7. Bagatin, I. A.; Legnani, C.; Cremona, M.; Mater. Sci. Eng., C 2009, 29, 267.

8. Legnani, C.; Reyes, R.; Cremona, M.; Bagatin, I. A.; Toma, H. E.; Appl. Phys. Lett. 2004, 85, 10.

9. Chen, H. W.; Lee, J. H.; Lin, B. Y.; Chen, S.; Wu, S. T.; Nature 2018, 7, 17168.

10. Bi, Y. G.; Feng, J.; Ji, J. H.; Yi, F. S.; Li, Y. F.; Liu, Y. F.; Zhang, X. L.; Sun, H. B.; Nanophotonics 2017, 7, 2.

11. Langhals, H.; Heterocycles 1995, 4, 477.

12. Williams, R. M.; Turk. J. Chem. 2009, 33, 727.

13. Nagao, Y.; Prog. Org. Coat. 1997, 31, 43.

14. Huang, C.; Barlow, S.; Marder, S. R.; J. Org. Chem. 2011, 6, 2386.

15. Spietschka, E.; Tröster, H.; US pat. 4.599.408, 1986.

16. Lukác, I.; Langhals, H.; Chem. Ber. 1983, 116, 3524.

17. Nowak-Król, A.; Shoyama, K.; Stolte, M.; Würthner, F.; Chem. Commun. 2018, 54, 13763.

18. Wicklein, A.; Koh, P.; Ghazaryan, L.; Thurn-Albrecht, T.; Thelakkat, M.; Chem. Commun. 2010, 46, 2328.
19. Thermo Fischer Scientific, Protein Biology Resource Library, Fluorescent Probes, available at https://www.thermofisher. com/br/en/home/life-science/protein-biology/protein-biologylearning-center/protein-biology-resource-library/pierceprotein-methods/fluorescent-probes.html, accessed in July 2020.

20. http://static.bdbiosciences.com/documents/multicolor_ fluorochrome_laser_chart.pdf, accessed in July 2020.

21. https://www.bu.edu/flow-cytometry/files/2013/06/ Fluorochromes-Brightness-Chart.pdf, accessed in July 2020.

22. Kratochvil, B.; Lorah, E.; Garber, C.; Anal. Chem. 1969, 41, 1793.

23. ChemBioDraw Ultra, v.11.0.1; CambridgeSoft, USA, 2007.

24. OriginPro 8.5; OriginLab Corporation, Northampton, MA, USA, 2010.

25. Bagatin, I. A.; Toma, H. E.; New J. Chem. 2000, 24, 841.

26. Valeur, B.; Molecular Fluorescence: Principles and Applications; Wiley VCH: Weinheim, Germany, 2002.

27. Vân Anh, N.; Schlosser, F.; Groeneveld, M. M.; van Stokkum, I. H. M.; Würthner, F.; Williams, R. M.; J. Phys. Chem. C 2009, 113,18358 .

28. Rodler, F.; Schade, B.; Jager, C. M.; Backes, S.; Hampel, F.; Bottcher, C.; Clark, T.; Hirsch, A.; J. Am. Chem. Soc. 2015, 137, 3308.

29. Ghosh, S.; Banik, D.; Roy, A.; Kundu, N.; Kuchlyan, J.; Sarkar, N.; Phys. Chem. Chem. Phys. 2014, 16, 25024.

30. Zhang, X. F.; Zhang, Y.; Liu, L.; J. Lumin. 2014, 145, 448.

31. Brouwer, A. M.; Pure Appl. Chem. 2011, 83, 2213.

32. Moutzouris, K.; Papamichael, M.; Betsis, S. C.; Stavrakas, I.; Hloupis, G.; Triantis, D.; Appl. Phys. 2013, B 116, 617.

33. Home, R.; Water and Aqueous Solutions; Wiley-Interscience: Toronto, 1972.

34. Bagatin, I. A.; Cruz, A. T.; Toma, H. E.; Politi, M. J.; Demets, G. J. F.; J. Inclusion Phenom. Macrocyclic Chem. 2005, 52, 189.

35. Compton, R. G.; Banks, C. E.; Understanding Voltammetry; University of Oxford: Oxford, UK, 2007.

36. Lee, S. K.; Zu, Y.; Herrmann, A.; Geerts, Y.; Mllen, K.; Bard, A. J.; J. Am. Chem. Soc. 1999, 121, 3513.

Submitted: January 7, 2020

Published online: July 17, 2020 